\title{
КЛІНІКО-ФУНКЦІОНАЛЬНІ АСПЕКТИ ВІДНОВНОГО ЛІКУВАННЯ ДІТЕЙ МОЛОДШОГО ШКІЛЬНОГО ВІКУ 3 ЦЕРВІКОГЕННИМ ГОЛОВНИМ БОЛЕМ НА ТЛІ НЕСТАБІЛЬНОСТІ В ШИЙНОМУ ВІДДІЛІ ХРЕБТА
}

\author{
○Н. В. Короленко, О. \\ Одеський обласний благодійний фонд реабілітації дітей-інвалідів «Майбутнє» \\ Клінічний відділ медичної реабілітації ДП «УКРНДІ МТ МОЗ України», м. Одеса
}

РЕЗЮМЕ. Актуальність проблеми вивчення головного болю (ГБ) у дітей обумовлюється поширеністю, складністю патогенетичних механізмів та невизначеністю алгоритмів і методичних підходів до терапії цього захворювання у вказаній віковій групі.

Метою дослідження було вивчення в динаміці (до лікування, після курсу та через 1 і 6 місяців після впливу) клінічного ефекту окремого та поєднаного застосування кінезіотейпування і лікувальної фізкультури (ЛФК) і їх впливу на стан гемодинаміки судин вертебробазилярного басейну, вегетативний баланс та психофізіологічний стан дітей молодшого шкільного віку з цервікогенним головним болем (ЦГБ) на тлі нестабільності в шийному відділі хребта.

Матеріал і методи. Клініко-функціональний стан у 96 дітей чоловічої та жіночої статі молодшого шкільного віку (6-11 років), які мали цервікогенний головний біль на тлі нестабільності в шийному відділі хребта впродовж більш ніж 6 місяців, вивчено із застосуванням клінічного і рентгенологічного методів, ультразвукової транскраніальної доплерографії, психофізіологічних тестів і аналізу варіабельності ритму серця.

Результати. Встановлено, що у дітей з ЦГБ найкращий клініко-функціональний ефект настає при поєднаному застосуванні кінезіотейпування і ЛФК, який зберігається ще 1 місяць та дещо зменшується через 6 місяців після лікування. Комплексний вплив призводить до сприятливої динаміки майже всіх показників обстеження і покращує клінічний стан (зменшення частоти і інтенсивності головного болю), більш значно та довготривало покращує гемодинаміку судин вертебробазилярного басейну (кровотік, пружноеластичні властивості судин, реакція на негативні екстравазальні впливи оточуючих структур, венозний відтік), психофізіологічний стан (нервово-психічна напруженість, увага, динамічна працездатність) і вегетативний статус хворих дітей, ніж окреме застосування означених методик. Досягнуті через 6 місяців після лікування клініко-функціональні ефекти окремого і поєднаного застосування кінезіотейпування і ЛФК є зіставними.

Висновок. Найбільшу ефективність ВЛ дітей з ЦГБ на тлі нестабільності ШВХ встановлено при комплексному застосуванні кінезіотейпування і ЛФК. Катамненстичне спостереження через півроку виявляє регрес позитивних результатів у частини хворих дітей, що підтверджує необхідність продовження тривалості курсу ВЛ або їх повторення не пізніше, ніж через 6 місяців.

КлючОВІ СлОВА: діти; цервікогенний головний біль; гемодинаміка вертебробазилярного басейну; психофізіологічний стан; вегетативний баланс; відновне лікування; кінезіотейпування; лікувальна фізкультура.

Вступ. Понад 40 \% дітей та підлітків, за різними даними, скаржаться на головний біль [1]. Цервікогенний цефалгічний синдром у дітей може бути одним з провідних проявів диспластичної нестабільності ШВХ, оскільки при станах, що призводять до компресії хребетних артерій або подразнення чутливих нервових корінців, симпатичних нервів виникає наступне рефлекторне напруження м'язів шиї і потиличної ділянки, що може бути субстратом болю [2, 3].

Актуальність проблеми вивчення ГБ у дітей обумовлюється також і тим, що не до кінця розроблені алгоритми і схеми терапії цього захворювання в цій віковій групі [4]. Останнім часом для відновного лікування (ВЛ) різної патології у дітей та дорослих використовують метод кінезіотейпування $[5,6]$.

Метою дослідження було вивчення в динаміці (до лікування, після курсу та через 1 і 6 місяців після впливу) клінічного ефекту окремого та поєднаного застосування кінезіотейпування і лікувальної фізкультури (ЛФК) і їх впливу на стан гемодинаміки судин вертебробазилярного басейну, вегетативний баланс та психофізіологічний стан дітей молодшого шкільного віку з цервікогенним головним болем (ЦГБ) на тлі нестабільності в шийному відділі хребта.

Матеріал і методи досліджень. Матеріалом для дослідження стали результати обстеження 96 дітей чоловічої та жіночої статі молодшого шкільного віку (6-11 років), які мали цервікогенний головний біль на тлі нестабільності в шийному відділі хребта впродовж більше 6 місяців, та 30 здорових дітей аналогічного віку. Після первинного обстеження вивчали результат впливу відновного лікування на динаміку стану дітей. Впродовж місяця пацієнти основної групи отримували відновне лікування в амбулаторних умовах Одеського обласного благодійного фонду реабілітації дітей-інвалідів «Майбутнє». Із основної групи було сфор- 
Огляди літератури, оригінальні дослідження, погляд на проблему, ювілеї

мовано три підгрупи дітей: дітям 1 підгрупи (36 осіб) було застосоване відновне лікування 3 включенням кінезіотейпування, дітям 2 підгрупи (30 осіб) була призначена ЛФК, діти 3 підгрупи (30 осіб) отримували кінезіотейпування і ЛФК в поєднанні.

Дана робота за організацією і методологією виконання відповідала положенням Консенсусу 3 біомедичної етики. Робота була проведена із дотриманням принципів доказової медицини. Участь дітей у дослідженні здійснювалася на підставі письмової інформованої згоди батьків (або опікунів) кожного пацієнта. Дослідження проводили 3 дотриманням конфіденційності щодо особистої інформації про пацієнтів.

Методи дослідження - клінічні, анкетування для кількісної оцінки головного болю за ВАШ, рентгенографічні, транскраніальна доплерографія (ТКДГ) судин голови та шиї з функціональним навантаженням, психофізіологічні (тест Люшера для оцінки рівня тривожності; оцінка розподілу (тест Шульте), обсягу (тест «Розвідник») і переключення (тест «Червоне і чорне») уваги; оцінка динамічної працездатності нервової системи (теппінг тест)), нейрофізіологічні (кардіоінтервалографія) для оцінки вегетативного статусу (тонусу та реактивності).

Методи аналізу - систематизація, кодування даних, математичні та статистичні методи обробки інформації [7].

Вид дослідження - клінічне відкрите контрольоване проспективне дослідження.

Результати й обговорення. Дослідження показало, що кожен із методів відновного лікування (ВЛ) приводить до односпрямованої сприятливої динаміки майже всіх показників, що вивчалися, i покращує клінічний стан (зменшення частоти і інтенсивності головного болю), гемодинаміку судин вертебробазилярного басейну, вегетативний баланс та психофізіологічний стан дітей молодшого шкільного віку з цервікогенним головним болем (ЦГБ) на тлі нестабільності в шийному відділі хребта.

Застосування кінезіотейпування привело до значного покращення клінічного стану дітей відразу після лікування - на головний біль не скаржилися 83,3 \% (30/36) дітей (медіана інтенсивності болю за ВАШ у решти 16,7 \% становила 1,0 бал). При віддаленому спостереженні - через 1 місяць після закінчення лікування, 27,8 \% (10/36) дітей скаржились на головний біль, а через 6 місяців 50,0 \% відзначали відсутність болю (15/30) (у більшості решти дітей медіана інтенсивності болю за ВАШ становила 2,0 бали).

Виконання курсу ЛФК привело до покращення клінічного стану дітей, що виявилося у зниженні частоти скарг на головний біль зразу після ліку- вання до 63,3 \% (19/30) та до 58,8 \% (10/17) через 6 місяців. Після лікування майже у половини цих дітей медіана інтенсивності головного болю за ВАШ становила 1,0 бал.

Поєднане застосування методик кінезіотейпування та ЛФК привело до значного покращення клінічного стану дітей зразу після лікування, що виявилося у зменшенні кількості дітей з головним болем до 13,3 \% (4/30) дітей. Через 1 місяць після закінчення лікування болю не відзначали 73,3 \% (22/30), а через 6 місяців - 61,54 \% (16/26) дітей не скаржились на головний біль. У більшості цих дітей медіана інтенсивності болю за ВАШ становила 1,0 бал.

При порівнянні впливу досліджених комплексів ВЛ на клінічний стан хворих дітей з ЦГБ кращий і більш довгостроковий клінічний ефект у вигляді зменшення частоти та інтенсивності головного болю настає після поєднаного застосування кінезіотейпування та ЛФК.

Порівняння показників гемодинаміки судин вертебробазилярного басейну виявило, що всі запропоновані комплекси ВЛ покращували кровотік як в інтракраніальних так і в екстракраніальних відділах обох хребетних артерій хворих дітей, однак застосування лише ЛФК приводило до менш виразної динаміки показників, порівняно з використанням як лише кінезіотейпування, так і поєднаного застосування кінезіотейпування і ЛФК. При поєднаному використанні кінезіотейпування і ЛФК досягнуте зразу після лікування зменшення асиметрії інтракраніального кровотоку зберігалося ще місяць, чого не було при використанні інших методів відновного лікування (рис. 1).

Також досліджені методи ВЛ приводили до однакового відтоку крові по обох очних венах і до кращого відтоку крові по прямому синусу при поєднаному застосуванні кінезіотейпування і ЛФК у хворих дітей.

При порівнянні досягнутих після лікування значень психофізіологічних тестів встановлено, що під впливом кінезіотейпування і ЛФК зменшується початково підвищений рівень тривожності хворих дітей за відхиленням від аутогенної норми та вегетативним коефіцієнтом (але не змінюється після виконання лише ЛФК і однаково покращується при окремому і поєднаному з ЛФК використанні кінезіотейпування).

Результати дослідження показали, що ВЛ 3 включенням кінезіотейпування у хворих дітей з ЦГБ зменшує підвищений рівень тривожності за тестом Люшера, покращує всі досліджені показники уваги та нейромоторної реакції (динамічної працездатності) дітей одразу після курсу лікування, які у віддаленому періоді (через 6 місяців) дещо погіршуються (рис. 2). 
Огляди літератури, оригінальні дослідження, погляд на проблему, ювілеї

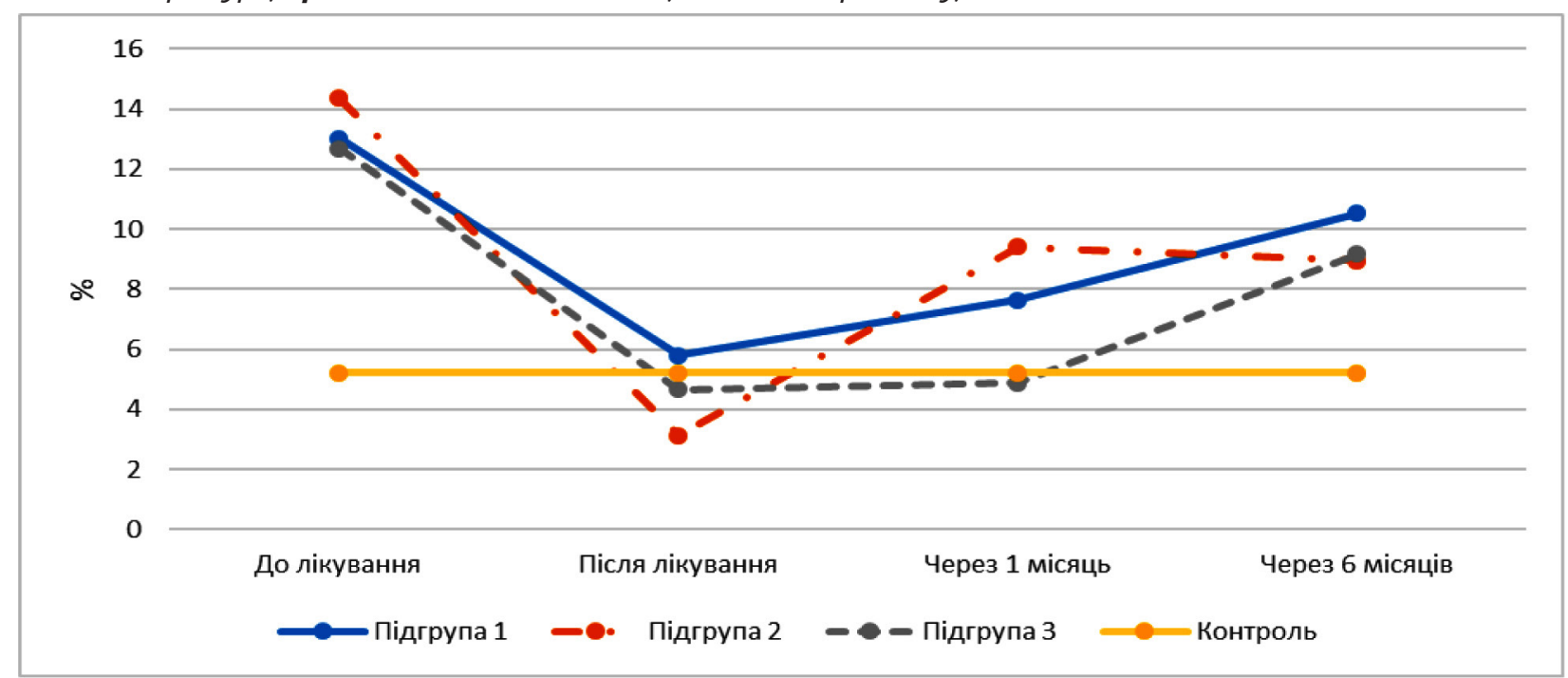

Рис. 1. Динаміка асиметрії кровотоку в інтракраніальних відрізках хребетних артерій у дітей з цервікогенним головним болем залежно від застосованих методів відновного лікування (медіани).

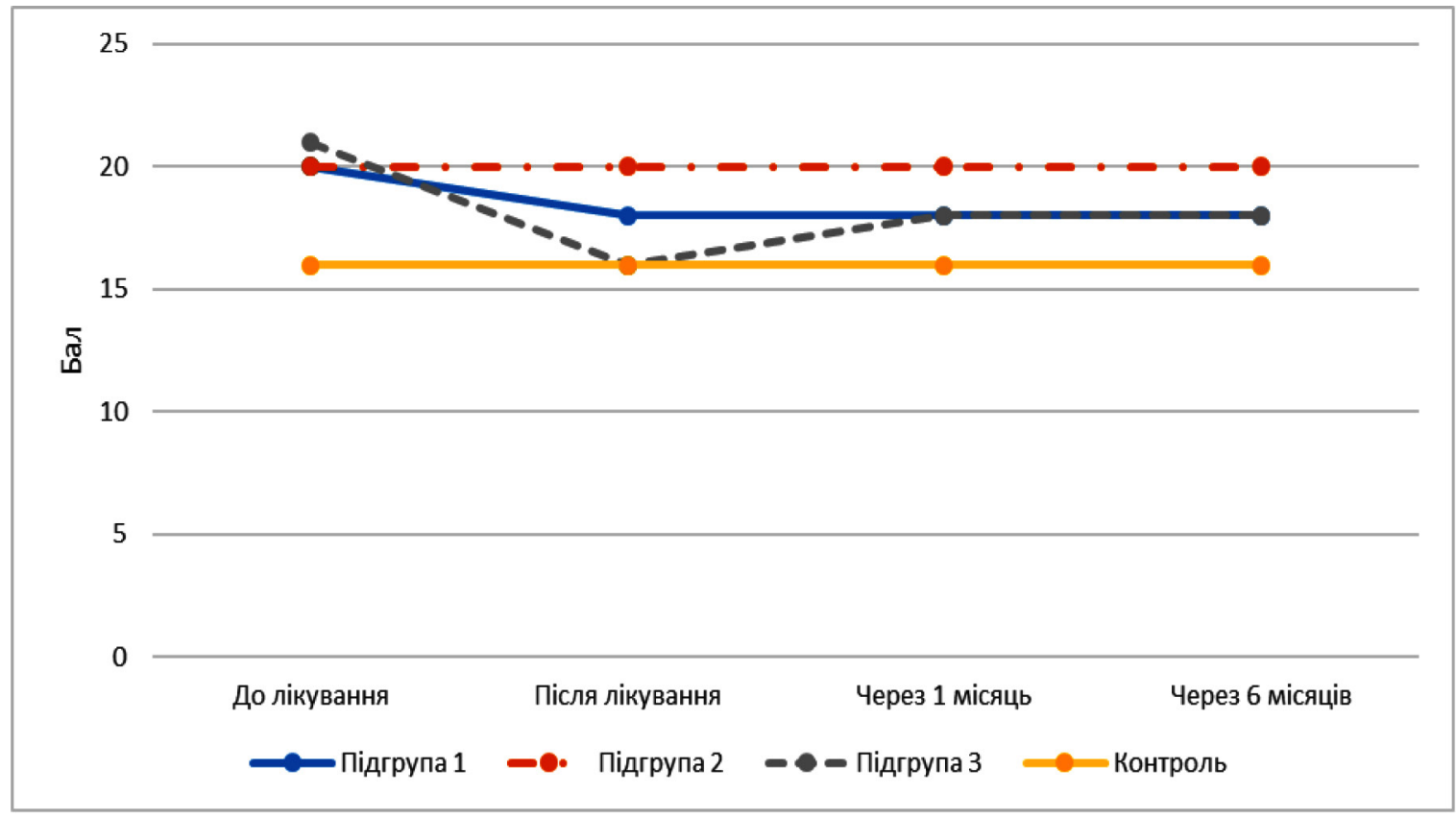

Рис. 2. Порівняльна динаміка рівня тривожності - відхилення від аутогенної норми за Тл (медіани залежно від точок обстеження).

Досягнуті ефекти переключення уваги та нейромоторної реакції дітей стають стійкими протягом всього спостереження, а інших психофізіологічних показників - більш короткотривалими.

Досягнуті після поєднаного застосування методик значення як статистичних, так і спектральних показників варіабельності ритму серця, були кращими, порівняно з окремим застосуванням досліджених методів відновного лікування. Поєднане застосування кінезіотейпування і ЛФК приводить до найбільшої оптимізації значення індексу напруження (IH) відразу після лікування і до пере- важання ейтонії (рис. 3) при зменшенні ваготонічного вегетативного тонусу у всіх точках дослідження, а також збільшення сприятливого симпатикотонічного характеру вегетативної реактивності при зменшенні гіперсимпатикотонічного типу, що засвідчує поліпшення вегетативної регуляції ритму серця у дітей з ЦГБ на тлі нестабільності ШВХ.

Висновки. 1. Отримані нами дані підтверджують найбільшу ефективність лікування ВЛ дітей 3 цервікогенним головним болем шляхом застосування кінезіотейпування і ЛФК. Комплексний вплив приводить до сприятливої динаміки майже 
Огляди літератури, оригінальні дослідження, погляд на проблему, ювілеї

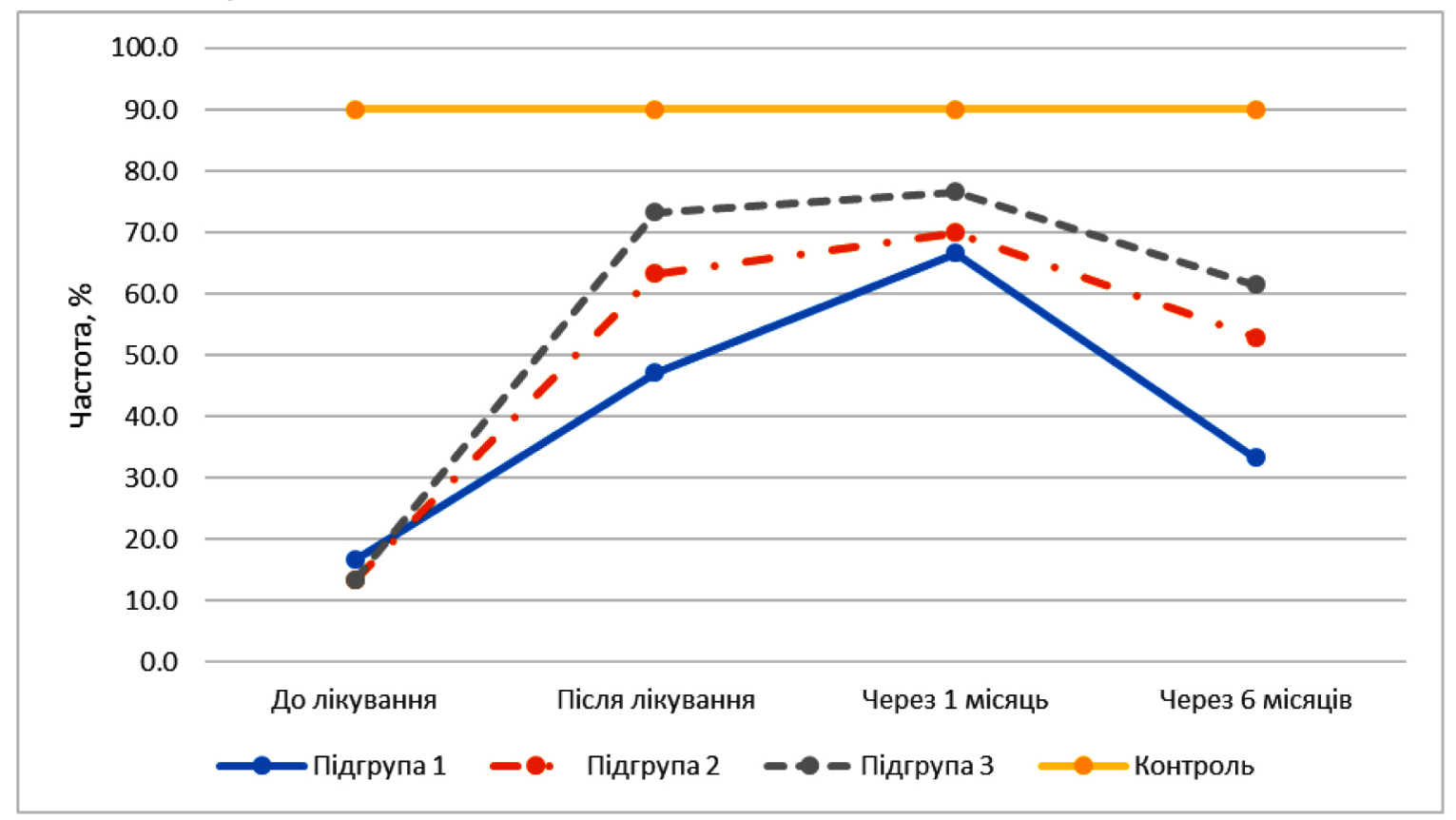

Рис. 3. Динаміка вегетативного тонусу: наявність ейтонії за індексом напруження у дітей з цервікогенним головним болем залежно від застосованих методів відновного лікування.

всіх показників обстеження і покращує клінічний стан (зменшення частоти і інтенсивності головного болю), більш значно та довготривало поліпшує гемодинаміку судин вертебробазилярного басейну (кровотік, пружноеластичні властивості судин, реакцію на негативні екстравазальні впливи оточуючих структур, венозний відтік), психофізіологічний стан (нервово-психічна напруженість, увага, динамічна працездатність) і вегетативний статус хворих дітей, ніж окреме застосування означених методик.

\section{ЛІТЕРАТУРА}

1. Юдельсон Я. Б. Эпидемиология головной боли у детей и подростков / Я. Б. Юдельсон, А. П. Рачин // Журнал неврологии и психиатрии. - 2004. - № 5. C. 50-53.

2. Кравченко А. И. Недифференцированная дисплазия соединительной ткани опорно-двигательной системы (диагностика, лечение) / А. И. Кравченко // Травма. - 2014. - Т. 15, №1. - С. 118-124.

3. Оптимальные методы диагностики нестабильности шейного отдела позвоночника у детей и подростков / Е. Э. Табе, О. А. Малахов, О. Б. Челпаченко [и др.] // Российский педиатрический журнал. - 2013. - № 1. С. 45-50.
2. Катамненстичне спостереження через півроку виявляє регрес позитивних результатів у частини хворих дітей, що підтверджує необхідність застосування більш довготривалих курсів ВЛ або їх повторення через 3-4 місяці.

Перспективи подальших досліджень. Оптимізація стану обстежених дітей спостерігається як при безпосередніх, так і при віддалених результатах дослідження, що підтверджує перспективність подальших досліджень ефективності застосування кінезіотейпування в педіатрії.

4. Haldeman, S. Cervicogenic headaches: a critical review / S. Haldeman, S. Dagenais // The Spine Journal. 2001. - Vol. 1, No. 1. - P. 31-46.

5. Ачкасов Е. Основы кинезиотейпирования : учебное пособие / Е. Ачкасов, М. Касаткин, О. Добровольский. - 2016. -77 с.

6. Клюйков А. И. Тейпирование и применение кинезиотейпа в спортивной практике : метод. пособие / А. И. Клюйков. - М. : РАСМИРБИ, 2009. - 140 с.

7. Мінцер О. П. Оброблення клінічних і експериментальних даних у медицині : навч. посібник для студентів / О. П. Мінцер, Ю. В. Вороненко, В. В. Власов. - К. : Вища школа, 2003. - 350 с. 
Огляди літератури, оригінальні дослідження, погляд на проблему, ювілеї REFERENCES

1. Yudelson, Ya. B., Rachin, A. P. (2004). Epidemiologiya golovnoy boli u detey i podrostkov [Epidemiology of headache in children and teenagers]. Zhurnal nevrologii i psikhiatrii - Journal of Neurology and Psychiatry, 5, 50-53 [in Russian].

2. Kravchenko, A.I. (2014). Nedifferentsirovannaya displaziya soedinitalnoy tkani oporno-dvigatelnoy sistemy (diagnostika, lecheniye) [Undifferentiated dysplasia of connective tissue of the musculoskeletal system (diagnosis, treatment)]. Travma - Trauma, 15 (1), 118-124 [in Russian].

3. Tabe, E.E., Malakhov, O.A., Chelpachenko, O.B., Zherdev, K.V., Taybulatov, N.I., \& Vasilchenko, V.V. (2013). Optimalnye metody diagnostiki nestabilnosti sheynogo otdela pozvonochnika u detey i podrostkov [Optimal methods for diagnosing cervical spine instability in children and adolescents]. Russkiy Pediatricheskiy Zhurnal - Russian Pediatric Journal, 1, 45-50 [in Russian].

4. Haldeman, S., \& Dagenais, S. (2001). Cervicogenic headaches: a critical review. The Spine J., 1 (1), 31-46.

5. Achkasov, Ye., Kasatkin, M., \& Dobrovolskiy, O. (2016). Osnovy kinezioteypirovaniya: uchebnoye posobiye [Fundamentals of kinesio taping: Textbook]. Moscow: RASMIRBI [in Russian].

6. Klyuykov, A.I. (2009). Teypirovaniye i primeneniye kinezioteypa $v$ sportivnoy praktike [Taping and application of kinesiotype in sports practice]. Moscow: RASMIRBI [in Russian].

7. Mintser, O.P., Voronenko, Yu.V., \& Vlasov, V.V. (2003). Obroblennia klinichnykh $i$ eksperementalnykh danykh $u$ medytsyni: navch. posibnyk dlia studentiv [Management of clinical and experimental data in medicine. A manual for students]. Kyiv: Vyshcha shkola [in Ukrainian].

\section{КЛИНИКО-ФУНКЦИОНАЛЬНЫЕ АСПЕКТЫ ВОССТАНОВИТЕЛЬНОГО ЛЕЧЕНИЯ ДЕТЕЙ МЛАДШЕГО ШКОЛЬНОГО ВОЗРАСТА С ЦЕРВИКОГЕННОЙ ГОЛОВНОЙ БОЛЬЮ НА ФОНЕ НЕСТАБИЛЬНОСТИ В ШЕЙНОМ ОТДЕЛЕ ПОЗВОНОЧНИКА}

๑Н. В. Короленко, О. В. Горша

Одесский областной благотворительный фонд реабилитации детей-инвалидов «Будущее»

Клинический отдел медицинской реабилитации ГП «УКРНИИ МТ МОЗ Украины», г. Одесса

PЕЗЮМЕ. Актуальность проблемы изучения головной боли (ГБ) у детей определяется распространенностью, сложностью патогенетических механизмов и неопределенностью алгоритмов и методических подходов к терапии данного заболевания в этой возрастной группе.

Целью исследования было изучение в динамике (до лечения, после курса и через 1 и 6 месяцев после воздействия) клинического эффекта отдельного и сочетанного применения кинезиотейпирования и лечебной физкультуры (ЛФК) и их влияния на состояние гемодинамики сосудов вертебробазиллярного бассейна, вегетативный баланс и психофизиологическое состояние детей младшего школьного возраста с цервикогенной головной болью (ЦГБ) на фоне нестабильности в шейном отделе позвоночника.

Материал и методы. Клинико-функциональное состояние в 96 детей мужского и женского пола младшего школьного возраста в возрасте 6-11 лет с цервикогенной головной болью на фоне нестабильности в шейном отделе позвоночника в течение более 6 месяцев изучено с применением клинического и рентгенологического методов, ультразвуковой транскраниальной допплерографии, психофизиологических тестов и анализа вариабельности ритма сердца.

Результаты. Установлено, что у детей с ЦГБ лучший клинико-функциональный эффект наступает при одновременном применении кинезиотейпирования и ЛФК, который таким остается еще 1 месяц и несколько уменьшается через 6 месяцев после лечения. Комплексное воздействие приводит к благоприятной динамике многих показателей обследования и улучшает клиническое состояние (уменьшение частоты и интенсивности головной боли), более значительно и длительно улучшает гемодинамику сосудов вертебробазилярного бассейна (кровоток, упругоэластичные свойства сосудов, реакция на негативные экстравазальные влияния окружающих структур, венозный отток), психофизиологическое состояние (нервно-психическая напряженность, внимание, динамическая работоспособность) и вегетативный статус больных детей, чем отдельное применение указанных методик. Достигнутые через 6 месяцев после лечения клинико-функциональные эффекты раздельного и сочетанного применения кинезиотейпирования и ЛФК являются сопоставимыми.

Вывод. Наибольшую эффективность ВЛ детей с ЦГБ на фоне нестабильности ШОП установлено при комплексном применении кинезиотейпирования и ЛФК. Катамненстические наблюдения через полгода обнаруживают регресс положительных результатов у части больных детей, что подтверждает необходимость продления курса ВЛ или их повторения не позднее, чем через 6 месяцев.

КЛЮЧЕВЫЕ СЛОВА: дети; цервикогенная головная боль; гемодинамика вертебробазилярного басейна; психофизиологическое состояние; вегетативный баланс; восстановительное лечение; кинезиотейпирование; лечебная физкультура. 


\title{
Огляди літератури, оригінальні дослідження, погляд на проблему, ювілеї \\ CLINICAL-FUNCTIONAL ASPECTS OF REHABILITATION TREATMENT OF PRIMARY SCHOOL AGED CHILDREN WITH CERVICOGENIC HEADACHE AGAINST A BACKGROUND OF CERVICAL SPINE INSTABILITY
}

\author{
ON. V. Korolenko, O. V. Gorsha \\ Odesa Regional Charitable Foundation Rehabilitation of Disabled Children "The Future" \\ Odesa Ukrainian Scientific and Research Institute of Transport Medicine
}

\begin{abstract}
SUMMARY. The problem of studying headache (HA) in children is actual because of its prevalence, complexity of pathogenetic mechanisms and absence of algorithms and methodological approaches to the therapy of the pathology in this age group.

The aim of the study was learning the dynamics (before treatment, after the course, and after 1 and 6 months after therapy usage) of the clinical effect of alone and combined usage of kinesio taping and physical therapy exercises and their effect on the hemodynamics of the vessels of the vertebrobasilar basin, the vegetative balance and the psychophysiological state of primary school aged children with cervicogenic headache against the background of cervical spine instability.

Clinical and functional status in 96 children (boys and girls) of primary school aged children (6-11 years old) who suffered from headache on the background of the cervical spine instability over 6-months long was studied using clinical and X-ray methods, transcranial Doppler ultrasound, physiological tests and analysis of cardiac rhythm variability.

It has been established that in children with cervicogenic headache the best clinical and functional effect occurs with the combined use of kinesio taping and physical exercise therapy. The reached therapeutic result remains at this level within a month and falls a little in 6 months after treatment. A combined influence leads to favorable dynamics of almost all indicators of the exam and improves the clinical condition (reduction of the frequency and intensity of headache), more significantly and longterm improves hemodynamics of the vessels of the vertebrobasilar basin (blood flow, elastic properties of vessels, reaction to negative extravasal effects of surrounding structures, venous outflow), psychophysiological state (neuro-psychic tension, attention, dynamic working ability) and vegetative status of sick children than separate usage of these methods. The clinical and functional effects of separate and combined usage of kinesio taping and exercise therapy reached in 6 months after treatment are comparable.

Conclusion. The greatest efficacy in the rehabilitation treatment of children with cervicogenic headache on the background of cervical spine instability is established with the compined application of kinesio taping and exercise therapy. The follow up observation after six months reveals a regression of positive results in some children, which confirms a necessity of prolongation of the course of the rehabilitation treatment or its repetition no later than after 6 months.

KEY WORDS: children; cervicogenic headache; hemodynamics of the vertebrobasilar basin; psychophysiological state; vegetative balance; rehabilitation; kinesio taping; exercise therapy.
\end{abstract}

